\title{
Noise signature on interval timing
}

\author{
Sorinel A Oprisan*, Derek N Novo \\ From 24th Annual Computational Neuroscience Meeting: CNS*2015 \\ Prague, Czech Republic. 18-23 July 2015
}

Among other essential adaptations is the capability of organisms to estimate durations in the seconds-to-hours range (interval timing). Such capabilities are critical for fundamental cognitive processes like decision making, rate calculation, and planning of action [1]. In their seminal work on computational modeling of interval timing, Matell and Meck [2] revitalized the striatal beat frequency (SBF) model that utilizes the coincident activation of a series of oscillators to code for different durations. They showed through numerical simulations that the SBF model is capable of reproducing two of the interval timing signatures: (a) precise timing, i.e. the model output peaks at the training/criterion time and (b) scalar timing, i.e. the error in timing increases linearly with the criterion time. The SBF model was capable of producing scalar timing only when different types of biologically realistic variances (frequency, memory, etc.) were considered [3].

In this work, we investigated what effect each type of variance/noise has on the shape of the SBF model out- put. In particular, we noticed that the experimentally measured response rate is not quite Gaussian (see Figure 1A) and instead has a long tail. Mathematically, the output function of set of coincidental (sinusoidal) oscillators is given by [3]:

$$
\operatorname{out}(t)=\sum \cos \left(2 \pi f_{i} T\right) \cos \left(2 \pi f_{i} t\right)
$$

where $T$ is the criterion time, $f_{i}$ are the frequencies of neural oscillators. The criterion time $T$ is learned during the training phase and stored/retrieved from the longterm memory with some errors. The firing frequencies $f_{i}$ of all neural oscillators also fluctuate. We found that memory variance $\left(s_{T}\right)$ preserves the Gaussian shape of the output function, whereas the frequency variance $\left(s_{f}\right)$ skews and has a long tail similar to experimental observations (see Figure 1B).

In addition to the significantly difference contributions to the shape of output functions, we also found that
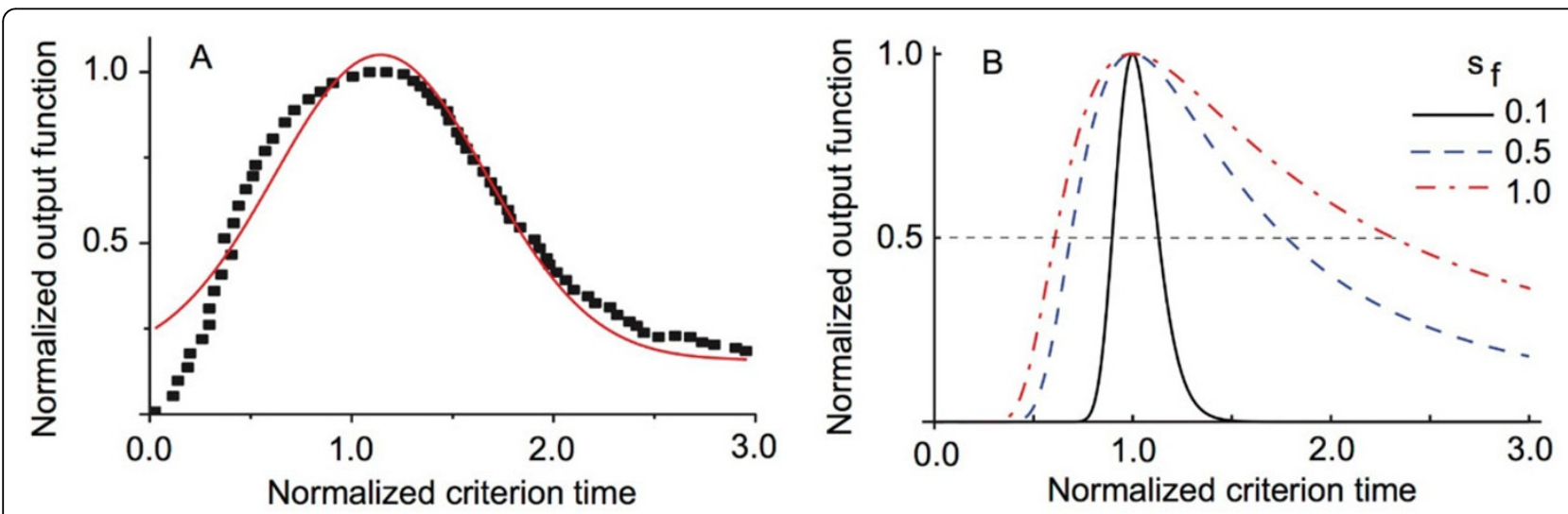

Figure 1 A. Normalized response for mice (squares - redrawn after [4]) versus normalized criterion time and the corresponding best Gaussian fit (continuous line). B. Theoretical output from SBF model with different frequency variances.

\footnotetext{
* Correspondence: oprisans@cofc.edu

Department of Physics and Astronomy, College of Charleston, Charleston, SC
} 29424, USA 
memory and frequency noises shift the peak of the Gaussian. Memory noise affects the storage/retrieval of criterion $T$ and shifts the peak of the output to the right, i.e. $t_{T}=T\left(1+_{T}\right)$, where ${ }_{\mathrm{T}}$ is a number that depends on the range of stored values of $T$ and the probability distribution function $\left(p d f_{T}\right)$ of the noise. Frequency variance shifts the peak of the output to the left, i.e. $t_{f}=$ $T /(1+f)$, where ${ }_{\mathrm{f}}$ is a number that depended on the range of frequencies and the $p d f_{f}$ of the noise.

\section{Acknowledgements}

This work was supported by the grant IOS CAREER 1054914 from the National Science Foundation.

Published: 18 December 2015

\section{References}

1. Gallistel CR: The organization of behavior Cambridge, MA: MIT Press; 1990.

2. Matell MS, Meck WH: Cortico-striatal circuits and interval timing: coincidence detection of oscillatory processes. Cognitive Brain Research 2004, 21(2):139-170.

3. Oprisan SA, Buhusi CV: What is all the noise about in interval timing? Philosophical Transactions of the Royal Society of London B: Biological Sciences 2014, 369(1637):20120459.

4. Buhusi CV, Aziz D, Winslow D, Carter RE, Swearingen JE, Buhusi MC: Interval Timing Accuracy and Scalar Timing in C57BL/6 Mice. Behavioral Neuroscience 2009, 123(5):1102.

doi:10.1186/1471-2202-16-S1-P180

Cite this article as: Oprisan and Novo: Noise signature on interval timing. BMC Neuroscience 2015 16(Suppl 1):P180.

\section{Submit your next manuscript to BioMed Central} and take full advantage of:

- Convenient online submission

- Thorough peer review

- No space constraints or color figure charges

- Immediate publication on acceptance

- Inclusion in PubMed, CAS, Scopus and Google Scholar

- Research which is freely available for redistribution

Submit your manuscript at www.biomedcentral.com/submit
C Biomed Central 